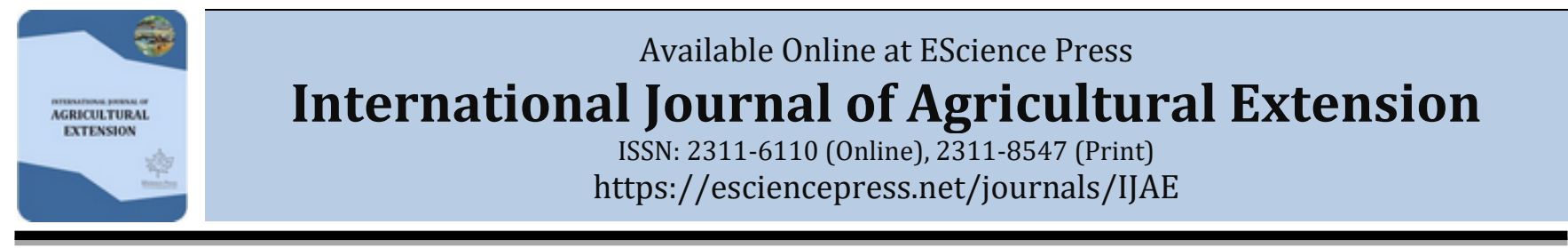

\title{
UTILIZATION OF SOYBEAN PRODUCTS AMONG RURAL HOUSEHOLDS IN ISEYIN LOCAL GOVERNMENT AREA OF OYO STATE
}

\author{
aOyewole F. Mojisola*, bOghenetejiri Digun-Aweto \\ ${ }^{a}$ Department of Agricultural Extension and Rural Development, University of Ibadan, Oyo State, Nigeria. \\ ${ }^{b}$ TREES, North-West University, Potchefstroom Campus, North-West, South Africa.
}

*Corresponding Author Email: oyemojidola2@yahoo.com

\section{A B S T R A C T}

Soybean is a cheap and important source of plant protein with numerous health benefits thus making it one of the researched plant crops which has drawn the attention of research institutions. This study was conducted in Iseyin Local government area of Oyo State to understand farmer's awareness of soya bean products, to also know their knowledge ability of the nutritional and health benefits and also the constraints facing the adoption of soya bean products. A structured interview schedule was employed to collect data from 120 households through a multistage sampling procedure. The data was analyzed using descriptive statistics such as percentages, mean and standard deviation, while inferential statistics such as chi-square and correlation were used in testing the hypothesis. The results revealed that a large proportion of the farmers were aware of different soybean products such as soymilk $(100 \%)$ soy cheese $(99.2 \%)$ and soybean cake $(85.2 \%)$. The major constraint reported was the short shelf life of soybean products. The results also revealed a significant relationship between farmers level of awareness of soybean products and utilization $(\mathrm{r}=0.286, \mathrm{p}<0.05)$ and between knowledge on nutrition and health benefits on the utilization of soybean products. This research calls for more efforts aimed at increasing the awareness of soybean products to help increase the nutritional status of rural households and communities through utilization of soybean products.

Keywords: Oyo-state, rural household, soybean, utilization.

\section{INTRODUCTION}

Nigeria is the largest soybean producer in Sub-Sahara Africa (IITA, 2009) which was first introduced into Nigerian in 1908 (Fennel, 1966) but the Malayan variety was the variety found to be commercially viable in the central part of Nigeria, Benue State (Root et al., 1987). Soybean is a highly valued and productive crop which fits into many agro climatic conditions. It is viewed as a grain with over 365 applications for not only for human consumption but for also animal and also has many industrial uses (Omotayo et al., 2007). Soybean is a cheap source of plant protein, having a good mix of essential amino acids. Adegoke et al. (2002) noted that the unsaturated fat content of soybeans, making it a healthy for the heart. In addition to the high protein content, it also provides a good amount of calories, fat, calcium, iron, and vitamins like thiamin, riboflavin, and niacin (Agwu et al., 2009). Soybean at the household level is of very significant importance, its use as an important substitute, because of its ability to be used in liquid, solid or powder form, making it valuable in the preparation of many ethnic dishes across Nigeria, and as a protein fortifier. Similarly, it has been used as a substitute in the preparation of condiments and seasonings. Soya bean oil can be converted into bread spread and also salad oil. In the Industrial sector, it was found to be used as an anti-corrosion agent, a significant ingredient in the production of disinfectants, pesticides, adhesives, inks, paints antibiotics and cosmetics (Ngalamu et al., 2012).

In the last 15 years, the International Institute for Tropical Agriculture (IITA) devoted efforts to improving productivity by developing higher-yielding varieties (IITA, 2006). Even though there has been substantial research work done on soybean research, there is still a huge gap between the level of empirical information available and the depth of adoption and utilization by resource-poor farmers in the area of the impact on 
health and nutrition Inadequate protein is a huge problem facing the Nigerian populace today and about 94 million Nigerians are living below the poverty line. Due to the expensive nature of protein and only a few rural households are able to include adequate protein into their diet, there is need for provision of a cheap alternative protein source. Oyesola \& Olujide (2000) noted that the contribution of the livestock sector which is an important component of the agricultural economy (providing animal protein to the populace), failed to contribute substantially in reducing the protein deficit gap nutritionally to Nigerians especially rural households. In an effort to reduce the shortage of protein, the Agricultural Development Program (ADP) has made series of efforts in promoting adoption and utilization of soybean products in the Eastern states of Nigeria with special emphasis on farm - families (Njoku, 2005). This was based on the premise of soybean as a cheap and inexpensive protein source of plant origin which can be easily cultivated. This study hence seeks to understand the impact of soybean utilization of rural households in the Iseyin local government area of Oyo State considering the promotion of crop in the area having laid emphasis on its effect on the nutrition and health of rural households to help combat protein deficiency. Dugje et al. (2009) noted that soybean production and utilization have the potential for cash for rural farmers, for food and nutrition, and soil fertility improvement.

This study will help determine the level of utilization of soybean products in relation to its contribution to solving nutrition issues relating to protein intake among rural households. The research also helps in examining farmer's awareness of various soybean products, their knowledge about the nutrition and health benefits.

The main objective of the study is to determine the level of utilization of soybean products in Iseyin local government of Oyo state. The specific objectives are to:

- identify the socio-economic characteristics of the respondents

- determine the respondents' level of awareness of various soybean products

- ascertain the level of knowledge on the nutrition and health benefits of soybean products

- identify constraints facing the utilization of soybean products in the study area.

Hypothesis: The hypotheses for the study are stated in the null form:
Ho1: There is no significant relationship between the respondent's awareness of the various soybean products and the utilization of soybean products

Ho2: There is no significant relationship between the respondent's level of knowledge on the nutrition and benefits of soybean and the utilization of soybean products.

\section{METHODOLOGY}

Study area: The study was carried out in Iseyin local government area of Oyo State, approximately $100 \mathrm{~km}$ North of Ibadanand is an integral part of Oke-Ogun, Oyo Statewith a population of 260,000 as per 2006 Census. It is bounded in the West by Ibarapa East and Kajola local governments, in the East by Oyo west local government, in the north by Itesiwaju local government and south by Ibarapa East local government. The major occupation in the area is farming while secondary occupation includes oil processing, soap making, garri, craftwork, trading, and artisan works. Oyo state in Nigeria was selected for this study because it is known to be a soybean production region

Sample selection: A multistage sampling procedure was employed in selecting a sample for this study. Using the African Development Programme (ADP) data as cited by AMREC (2007), six local government areas were identified namely; Iseyin, Oyo West, Saki West, Afijo, Atiba, and Atisbo. Simple Random sampling technique was used to select Iseyin as one of the local government areas with prominence soybean production. From the selected LGA's four wards were selected from the eight wards, representing $50 \%$. Three villages from each of the four wards were randomly selected to arrive at a total of twelve villages where the study was conducted. A simple random sampling technique was used to select 41 households from Ado awaye village with the highest number of respondents (52) and 9 respondents each from 11 households in the other villages respectively. Seventy-four percent of 162 respondents were used for the study giving a total of 120 respondents.

\section{Measurement of variables}

\section{Independent variables}

Age: Respondents were asked to state their age in years

Sex: Respondents were asked to indicate their sex. A score of 1 was assigned to male while 2 was assigned to female.

Marital Status: Respondents were asked to indicate their marital status, single: 1, married: 2, divorced: 3 .

Educational background: Respondents were asked to 
indicate the highest level of education attained from the following: no formal education, primary education, secondary education, and tertiary education.

Awareness of soybean products: Level of knowledge on the nutrition and health benefits of soybean products were all measured using 1 for yes and 0 for no. The mean score that was generated was used to categorize respondents above the mean score as high level of awareness and high level of knowledge respectively and those below the mean score as low level of awareness of utilization of soybean products and low level of knowledge on the health and nutrition benefits of soybean products.

Table 1. Sampling of respondents in the study area.

\begin{tabular}{lccc}
\hline Villages & Percentage & Household & $\begin{array}{c}\text { Total } \\
\text { Population }\end{array}$ \\
\hline AdodoAwaye & 19 & 52 & 30 \\
OdoOgun & 5 & 11 & 9 \\
Abugada & 5 & 11 & 9 \\
Otiri & 5 & 11 & 9 \\
Idi-Iya & 5 & 11 & 9 \\
Idi-Ori & 5 & 11 & 9 \\
Osanetu & 5 & 11 & 9 \\
Odo-Agba & 5 & 11 & 9 \\
Adugbe & 5 & 11 & 9 \\
Atibaba & 5 & 11 & 9 \\
Aba Serafu & 5 & 11 & 9 \\
Agbede Idi Emi & 5 & 11 & 9 \\
Total & 69 & 162 & 120 \\
\hline
\end{tabular}

Constraints: constrains were determined by asking the respondents to rate a list of possible constraints on a scale of $0-2$. Severe constraints for 2 , mild constraint had a score of 1 and no constraint had a score of 0 . The constraints were ranked on basis of acquired mean value.

Dependent variable: Level of the utilization of soybean products in Iseyin local government area of Oyo State was the dependent variable in the study. The selected soybean products were listed, and respondents were asked to indicate the products they utilized using a 3 point scale ranging from 0-2. Never was given a score of 0 , occasionally was scored as 1 and frequently was scored as 2 . The mean score was generated. Respondents above the mean were categorized as having high level of utilization while those below the mean score were regarded as having low level of utilization.
The date was analyzed with descriptive statistics using frequencies, percentages, and means while inferential statistical tools such as chi-square and correlation were used to analyze the hypothesis.

\section{RESULTS AND DISCUSSION}

The age distribution of the respondents is shown in Table 2, showing that $30 \%$ of the respondents were within the age group of 32-51 years, while the least groups $(0.8 \%)$ comprised of individuals under the age of 21 and over the age of 72 . Thus, implies that the utilization of soybean products cuts across most age groups which is in line with the findings of Amusat et al. (2013). The results also showed $67.3 \%$ of women were more involved in soybean production and utilization than males (26.7\%). The FAO report of 2001 reported that women are very involved in the processing of agricultural products with soybean not being an exception.

Table 2. Distributions of respondents on Selected Socioeconomic characteristics ( $\mathrm{n}=120)$.

\begin{tabular}{lccc}
\hline Variables & Frequency & Percentage & $\overline{\boldsymbol{x}}$ \\
\hline \multicolumn{4}{c}{ Age (in years) } \\
\hline$\leq 21$ & 3 & 0.8 & \\
$21-31$ & 16 & 13.3 & $44 . .28$ \\
$32-41$ & 36 & 30.0 & \\
$42-51$ & 36 & 30.0 & \\
$52-61$ & 23 & 19.2 & \\
$62-71$ & 7 & 0.8 & \\
$\geq 72$ & 1 & 26. \\
\multicolumn{5}{c}{ Sex } \\
\hline Male & 32.0 & 67.3 \\
Female & 68.0 & 5.8 \\
\hline \multicolumn{5}{c}{ formal } & 7 & 19.2 \\
education & \multicolumn{4}{c}{ Eduanal Qualification } \\
Primary & 23 & 41.7 \\
Secondary & 50 & 33.3 \\
Tertiary & 40 &
\end{tabular}

The results indicates that less than half of the respondents (41.7\%) had a secondary education , 33.3\% had tertiary education while only $19.2 \%$ had primary education and $5.8 \%$ had no form of formal education suggesting that a large proportion of the respondents have minimal education necessary for sourcing information that can play a huge role in assessing 
information which can contribute to the knowledge on nutrition and health benefits of soy bean, thus influencing their utilization of soybean products. This is in line with the findings of Ajao et al. (2012) indicating that the higher the level of education of farmers, the higher their level of utilization of soybean products.

Table 3a, shows all the respondents (100\%) were cognizant of the fact that soybean can be used to make soy cheese. and $99.2 \%$ were conscious of soy milk production. The high level of awareness by respondents $(62 \%)$ as shown in Table $3 \mathrm{~b}$ may be attributed to effective extension activities, enlightenment, education and or effective use of communication channels. The result is in line with the findings of Njoku (2005) noting that respondents $(66.6 \%)$ were aware of soybean products and consumed soy flour regularly. The study recorded a $100 \%$ awareness which is an indication of good extension agent services.

Table 3a. Distribution showing the awareness of respondents on soybean products.

\begin{tabular}{lcccc}
\hline Soybean Products & \multicolumn{2}{c}{ Yes } & \multicolumn{2}{c}{ No } \\
\cline { 2 - 5 } & Frequency & Percentage & Frequency & Percentage \\
\hline Soybean can be used to make cheese & 120 & 100 & 0 & 0 \\
Milk can be extracted from Soybean & 119 & 99.2 & 1 & 8 \\
Fermented to make soy locust bean & 118 & 98.3 & 2 & 1.7 \\
Mixed with cowpea paste to make soybean cake & 112 & 93.3 & 8 & 6.7 \\
Mixed with flour to make soy cake & 99 & 82.5 & 21 & 17.5 \\
Can be processed into soy flour & 95 & 79.2 & 25 & 20.8 \\
Mixed with maize paste to make soy pap & 82 & 68.3 & 38 & 31.7 \\
Made into soy candy & 75 & 62.5 & 45 & 37.5 \\
Used to make soy garri & 68 & 56.7 & 52 & 43.3 \\
\hline
\end{tabular}

Table 3b. Categorization of Respondents' by their awareness level of utilization of soybean products.

\begin{tabular}{lcccccc}
\hline Level & Frequency & Percentage & Mean & Standard deviation & Minimum & Maximum \\
\hline Low & 46 & 62.0 & 5.74 & 1.71 & 3.0 & 18.0 \\
High & 74 & 38.0 & & & & \\
\hline
\end{tabular}

Table 4a shows that a large proportion of respondents had knowledge about the following statements: Soy milk is rich in protein, calories, and fat $(97.5 \%)$, Soy locusant is a good source of calcium, iron and vitamin (95\%), Consumption of soy pap reduces ulcer development (91.7\%) and Inclusion in diet reduces risk of disease (88.3\%). The other statements had knowledge level below $50 \%$ such as Soybean cake is a rich source of polyunsaturated fatty acid (49.2\%), Soy milk increases the chance of obesity $(29.2 \%)$ and Soy milk cannot supplement as weaning food for infants $(17.51 \%)$. Table $4 \mathrm{~b}$ concluded that soybean farmers $(60 \%)$ in Iseyin had high awareness of soybean nutritional and health benefits while $40 \%$ of respondents had low knowledge.

Table 4a. Distribution showing respondents' knowledge on the nutrition and health benefits of soybean products.

\begin{tabular}{lcccc}
\hline Knowledge Statements & \multicolumn{2}{c}{ Yes } & \multicolumn{2}{c}{ No } \\
\cline { 2 - 5 } & Frequency & Percentage & Frequency & Percentage \\
\hline Soy milk is rich in protein, calories and fat & 117 & 97.5 & 3 & 2.5 \\
Soy iru is a good source of calcium, iron, and vitamin & 114 & 95.0 & 6 & 5.0 \\
Consumption of soy pap reduces ulcer development & 110 & 91.7 & 10 & 8.3 \\
Inclusion in the diet reduces the risk of disease & 106 & 88.3 & 14 & 11.7 \\
Soy milk reduces the risk of diabetes & 106 & 88.3 & 14 & 11.7 \\
Soybean cake is a rich source of polyunsaturated fatty acid & 59 & 49.2 & 61 & 50.8 \\
Soy cheese cannot supplement for fish and meat & 56 & 46.7 & 64 & 53.3 \\
Soy milk increases the chance of obesity & 35 & 29.2 & 85 & 70.8 \\
\hline
\end{tabular}


Soy garri consumption increases chances of high blood pressure

Soy milk cannot supplement as weaning food for infants

23

19.2

97

80.8

Soy garri does not contain as much nutrient as whole

21

17.51

99

82.5

cassava garri

19

15.8

101

84.2

Soy oil has cholesterol

16

13.3

104

86.7

Table 4b. Categorization of Respondents' Knowledge on Health and Nutrition benefits of Soybean products.

\begin{tabular}{lcccccc}
\hline Level & Frequency & Percentage & Mean & Standard deviation & Minimum & Maximum \\
\hline High & 72 & 60.0 & 5.74 & 1.71 & 9.0 & 18.0 \\
Low & 48 & 40.0 & & & & \\
\hline
\end{tabular}

Table 5 revealed that majority of the respondents $(99.2 \%)$ got their information about soybean products utilisation from extension agents while the least proportion of them $(20 \%)$ has print media as their information source. Findings are contrary to those of Olatunji et al. (2012) as reported that friends, neighbours and farmers were most important sources of information about soybean products utilisation.

Table 5. Sources of Information on Utilization of Soybean Products.

\begin{tabular}{lcccc}
\hline Source of information & \multicolumn{2}{c}{ Yes } & \multicolumn{2}{c}{ No } \\
\hline Extension Agent & Frequency & Percentage & Frequency & Percentage \\
Television or radio & 119 & 99.2 & 1 & 0.8 \\
Print media (leaflet, poster) & 75 & 62.5 & 45 & 37.5 \\
Friends or neighbor & 24 & 20 & 96 & 80 \\
\hline
\end{tabular}

The result of analysis as indicated on Table 6 revealed that the short shelf life of soybean products is the constraint of the highest importance (64.2\%), next to this is the unavailability of adequate processing skills (46.7\%) while the least constraint is the processing time of production of soybean derivatives. This is an indication that soybean is well accepted as a salient ingredient of household diet because of its palatability, availability in the market and very marketable. On the contrary, farmers reported the inadequate processing skills and high drudgery involved are major constraints corroborating the results of New Nigeria Foundation (2007), thus negatively affecting the choice of soy products in diet despite high acceptance levels even though it is a good protein replacement for high priced animal protein.

The utilization of soybean for milk, cheese, soup, purpose rank highest which is in line with Fabiyi (2006), while utilization in garri, ogi, flour, and bean cake are relatively low. The Table 7a below shows the list of products in order of the highest frequency to the least utilized. Soymilk is a very good alternative to dairy milk, and especially for lactose intolerant individual. Table $7 \mathrm{~b}$ revealed that respondents (50.8\%) had high level of utilization of soybean products while $49.2 \%$ had low level of utilization.

Table 6. Constraints to the utilization of Soybean Products.

\begin{tabular}{|c|c|c|c|c|c|c|c|c|}
\hline \multirow[t]{2}{*}{ Constraints } & \multicolumn{2}{|c|}{ Severe } & \multicolumn{2}{|c|}{ Mild } & \multicolumn{2}{|c|}{ Nil } & \multirow[t]{2}{*}{ Mean } & \multirow[t]{2}{*}{ Rank } \\
\hline & Frequency & Percentage & Frequency & Percentage & Frequency & Percentage & & \\
\hline $\begin{array}{l}\text { Short post } \\
\text { processing } \\
\text { shelf life }\end{array}$ & 77 & 64.2 & 27 & 22.5 & 16 & 13.3 & 6.63 & $1^{\text {st }}$ \\
\hline $\begin{array}{l}\text { Inadequate } \\
\text { processing } \\
\text { skills }\end{array}$ & 56 & 46.7 & 53 & 44.2 & 11 & 9.2 & 6.58 & $2^{\text {nd }}$ \\
\hline
\end{tabular}




\begin{tabular}{|c|c|c|c|c|c|c|c|c|}
\hline $\begin{array}{l}\text { High } \\
\text { processing } \\
\text { drudgery }\end{array}$ & 15 & 12.5 & 63 & 52.5 & 42 & 35 & 4.82 & $3^{\text {rd }}$ \\
\hline $\begin{array}{l}\text { Scarcity of } \\
\text { soybean } \\
\text { products }\end{array}$ & 5 & 4.2 & 37 & 30.8 & 78 & 65 & 3.78 & $5^{\text {th }}$ \\
\hline $\begin{array}{l}\text { Foot } \\
\text { habit/taboo }\end{array}$ & 2 & 1.7 & 27 & 22.5 & 91 & 75.8 & 3.28 & $6^{\text {th }}$ \\
\hline $\begin{array}{l}\text { Low } \\
\text { palatability }\end{array}$ & 7 & 5.8 & 11 & 9.2 & 102 & 85 & 3.13 & $7^{\text {th }}$ \\
\hline Lack of time & 2 & 1.7 & 20 & 16.7 & 98 & 81.7 & 3.09 & $8^{\text {th }}$ \\
\hline $\begin{array}{l}\text { Low household } \\
\text { acceptance }\end{array}$ & 8 & 6.7 & 68 & 56.7 & 44 & 36.7 & 4.70 & $4^{\text {th }}$ \\
\hline
\end{tabular}

Table 7a. Distribution of respondent's utilization of soybean products.

\begin{tabular}{lcccccc}
\hline Soybean products & \multicolumn{2}{c}{ Frequently } & \multicolumn{2}{c}{ Occasionally } & \multicolumn{2}{c}{ Never } \\
\cline { 2 - 7 } & Frequency & Percentage & Frequency & Percentage & Frequency & Percentage \\
\hline Soymilk & 79 & 65.8 & 41 & 34.2 & 0 & 0 \\
Soy Cheese & 71 & 59.2 & 46 & 38.3 & 3 & 2.5 \\
Soy iru & 46 & 38.3 & 66 & 55 & 8 & 6.7 \\
Soy snacks & 23 & 19.2 & 62 & 51.7 & 35 & 29.2 \\
Cooking oil & 21 & 17.5 & 72 & 60.0 & 27 & 22.5 \\
Soy Akara & 14 & 11.7 & 51 & 44.5 & 55 & 45.8 \\
Soy bean cake & 12 & 10 & 38 & 31.7 & 70 & 58.3 \\
Soy soup & 11 & 9.2 & 93 & 77.5 & 16 & 13.3 \\
Soy pap & 10 & 8.3 & 15 & 12.5 & 95 & 79.2 \\
Soy garri & 7 & 5.8 & 5 & 4.2 & 108 & 90 \\
Soy flour & 5 & 4.2 & 78 & 65 & 37 & 30.8
\end{tabular}

Table 7b. Categorisation of respondents' knowledge on health and nutrition benefits of Soybean products.

\begin{tabular}{lccccc}
\hline Level & Frequency & Percentage & Mean & Minimum & Maximum \\
\hline High & 61 & 50.8 & 10.0 & 1.00 & 22.0 \\
Low & 59 & 49.2 & & & \\
\hline
\end{tabular}

Table 8. Pearson Product Moment Correlation (PPMC) on the relationship between the respondent's level of awareness of soybean products and the utilization of soybean product.

\begin{tabular}{lccc}
\hline Variable & r-value & $\mathrm{p}$-value & Decision \\
\hline Level of awareness of Soybean Products and Utilization of Soybean Products & 0.286 & 0.007 & Significant \\
\hline
\end{tabular}

Table 9. Pearson Product Moment Correlation (PPMC) on the relationship between the Respondent's Knowledge of Soybean Products and the Utilization of Soybean Product. $(\mathrm{n}=120)$.

\begin{tabular}{llll}
\hline Variable & r-value & $\mathrm{p}$-value & Decision \\
\hline Knowledge of Soybean Products and Utilization of Soybean Products & 0.281 & 0.000 & Significant \\
\hline
\end{tabular}

\section{Test of hypothesis}

Hypothesis 1: There was no significant relationship between the respondents of awareness of Soybean
Products and the Utilization of Soybean Products.

The results of analysis on Table 8 shows that there was a significant relationship between respondents level of 
awareness of soybean products and utilization of soybean products $(\mathrm{r}=0.286, \mathrm{p}<0.0)$. The implication of this shows that sources of information for soybean products have an influence on its utilization due to awareness created by various information channels which are in line with the findings of Dugje et al. (2009).

Hypothesis 2: There was no significant relationship between respondents' knowledge on the nutrition and health benefits of soybean products and the utilization of soybean products.

Table 9 indicates that there was a significant relationship between respondents' level of knowledge $(p>0.05)$ on the nutrition and health benefits of soybean utilization. This suggests that the respondent's level of knowledge on the nutritional and health benefits of soybean products have influence on its utilization. Thus, the null hypothesis is rejected.

\section{CONCLUSION AND RECOMMENDATIONS}

It was discovered that a large proportion of the individuals involved in soybean processing and development into soybean products were women who also had other businesses as secondary income generation sources. The results also showed that most of them had high awareness level about some soybean products like soymilk, soy cheese and soy iru, which is significant to their utilization of soybean products.

The respondents also had some knowledge of nutritional and health benefits of soybean products, indicating that there was some level of awareness of the importance of soybean nutritionally, while there was a little hindrance to the utilization of soybean products already established. Based on the findings of this research the following recommendations were suggested;

- Awareness of soybean products needs to be sustained and improved on by focusing more attention on soy candies, snacks, soy garri to farmers in a bid to help improve their income but also wellbeing. This can be achieved through campaigns, workshops, and seminars. The diversification of soy products creates a wider range of options while simple processing skills will facilitate soybean adoption in diets

- Non-governmental organizations need to be actively involved in promoting the importance of proper nutrition and the potentials of soybean to contribute effectively to nutrition.

- Women in Agriculture (WIA) and extension services need to collectively be involved in pursuing special outreach programs to women in villages to assist in teaching nutritional benefits and methods of preparation of soybean products. Furthermore, campaigns emphasizing the nutritional values of soybean focusing on children, infants, and nursing mothers and pregnant women require attention.

- Credit funds should be made available to farmers by credit institutions at the low interest rate and without difficulty in accessing loans

\section{REFERENCES}

Adegoke, G., Gbadamosi, R., Evwoerhurhoma, F., Uzopeters, P., Falade, K., Itiola, O., Moody O. \& Skura, B. (2002). Protection of maize (Zea mays) and soybeans (Glycine max) using Aframomumdanielli. European Food Research and Technology, 214(5), 408-411.

Agwu, O. E., Okon, A. N., \&Udoh, F. D. (2015). A comparative study of diesel oil and soybean oil as oil-based drilling mud. Journal of Petroleum Engineering, 2015.

Ajao, A. O., Ogunniyi, L. T., \&Adepoju, A. A. (2012). Economic efficiency of soybean production in OgoOluwa local government area of Oyo state, Nigeria. American Journal of Experimental Agriculture, 2(4), 667.

Amusat, A. S., \& Ademola, A. O. (2013). Utilisation of soybean in Oniyo community of Oyo State, Nigeria. Global Journal of Science Frontier Research Agriculture \& Veterinary, 13(7), 6-14.

Dugje, I. Y., Omoigui, L.O., Ekeleme, F., Bandyopadhyay, R., Kumar, P.L. \& A.Y. Kamara. (2009). Farmers' Guide to Soybean Production in Northern Nigeria. IITA: Ibadan

Fabiyi, E. F. (2006). Soyabean Processing, Utilization and Health Benefits. Pakistan Journal of Nutrition, 5 (5), 453-457.

Fennel, M.A. (1966) Present status of research on edible legumes in Western Nigeria. A paper presented at the first Nigerian Legume conference center, IITA, Ibadan. August 1966

IITA, (2006). Institute, New York. International Institute of Tropical Agriculture (IITA). 2009. Soybean (Glycine max.) Available at http://www.iita.org.soybean

International Institute for Tropical Agriculture, (2008). Research for Africa www.iita.org/coms.

Mathews-Njoku, E. (2005). Adoption of soya bean products in Owerri North Local Government Area 
of Imo State, Nigeria. Agrosearch, 7(1), 17-22.

Matthews-Njoku, E.C. (2005). Adoption of Soybean Products in Owerri North Local Government Area of Imo State, Nigeria. Agrosearch, 7(1), 22-27.

Naaz, A., Yellayi, S., Zakrocymski, M.A., Bunick, D., Doerge, D.R., Lubahn, D.B., Helferich, W.G. \& Cooke, P.S. (2003). The soy isoflavonegenistein decreases adipose desposition in mice. Endodrinol, 144, 3315-3320

National Population Commission. (2006). National Population Census. Abuja: National Population Commission.

Ngalamu, T., S. Meseka \& M. Ashraf. (2012). Performance of soybean (Glycine max L Merrill) genotypes under different planting dates in Sennar State of the Sudan. Journal of Applied Biosciences, 49, 3363-3370.

Olatunji, S.O., Etuk, U.R. \& O. M. Adesope. (2012). Factors Related to continuity in utilization of Soya Bean products by farm-families in Abia State, Nigeria. Journal of Agricultural Science, 3(1), 15-20.

Omotayo, A. M., Olowe, V.I.O., Fabusoro, E., Babajide, J.M.
Ojo, D.K. \& D. A. Adegbite. (2007). Commercial Demand for Soybean in Nigeria. Making Nigerian Agricultural Markets Work for the Poor. Pr op Com Monograph Series 29. Agricultural Media Resources and Extension Centre (AMREC). Abuja: Department for International Development.

Oyekunle, O., Onifade, O. T., Ayanda, I. F., Amusat, A. S., \&Bolarinwa, K. K. (2014). Constraints Associated with Cultivation and Utilization of Soyabean by Farmers in Ogun State, Nigeria. Constraints, 4(12).

Oyesola O.B. \& Olujide M.G. (2000). Participation of Livestock Farmers in Nigeria Agricultural Insurance Scheme. A case study of Iseyin Local Government Area of Oyo State. In: Proceeding of the 5th Annual Conference of the Animal Science Association of Nigeria, held at Port Harcourt, September 19-22, p213-214.

Root W.R., Oyekan P.O., Dashiell K.E. (1987). West and Central Africa: Nigeria sets example for expansion of soybean. In Soybeans for the Tropics Research Production and Utilization. p. 230.

Publisher's note: EScience Press remains neutral with regard to jurisdictional claims in published maps and institutional affiliations.

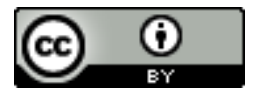

Open Access This article is licensed under a Creative Commons Attribution 4.0 International License, which permits use, sharing, adaptation, distribution and reproduction in any medium or format, as long as you give appropriate credit to the original author(s) and the source, provide a link to the Creative Commons license and indicate if changes were made. The images or other third-party material in this article are included in the article's Creative Commons license, unless indicated otherwise in a credit line to the material. If material is not included in the article's Creative Commons license and your intended use is not permitted by statutory regulation or exceeds the permitted use, you will need to obtain permission directly from the copyright holder. To view a copy of this license, visit http://creativecommons.org/licenses/by/4.0/.

(C) The Author(s) 2019. 